\title{
The theophylline-enoxacin interaction: I. Effect of enoxacin dose size on theophylline disposition
}

\begin{abstract}
Theophylline interacts pharmacokinetically with a variety of other drugs. Recently enoxacin was found to change theophylline's disposition. In a four-subject, four-way crossover study enoxacin was administered every 12 hours at four levels $(0,25,100$, and $400 \mathrm{mg})$ for 14 doses. With the ninth dose of enoxacin, $200 \mathrm{mg}$ theophylline was coadministered. Blood and urine samples were assayed by sensitive and specific assays for the parent drugs and their metabolites. Significant reduction in the formation of theophylline's three major metabolites occurred on coadministration of enoxacin. At the $\mathbf{4 0 0} \mathbf{~ m g}$ dose level, enoxacin caused a threefold decrease in theophylline's plasma clearance, a fourfold decrease in the urinary recovery of 3-methylxanthine and 1,3-dimethylurate, and a threefold decrease in the recovery of I-methylurate. (Cuin Pharmacol Ther 1988;44:579-87.)
\end{abstract}

\begin{abstract}
Mark C. Rogge, PhD, William R. Solomon, MD, Allen J. Sedman, MD, PhD, Peter G. Welling, PhD, Roger D. Toothaker, PhD, and John G. Wagner, PhD Ann Arbor, Mich.
\end{abstract}

Theophylline has been used extensively for many years in the treatment of chronic obstructive pulmonary disease. Because it has a realtively narrow therapeutic index, theophylline can readily cause a variety of unpleasant and serious side effects. ${ }^{1}$ Countless factors have been implicated in the development of theophylline toxicity (e.g., age, smoking habits, underlying disease, and concomitant drug use. $)^{2}$ In virtually all of the studies conducted on such factors a shift in some defined pharmacokinetic parameter explained the development of toxicity.

Theophylline's primary route of elimination in humans is through hepatic metabolism. Tang-Liu et al. ${ }^{3}$ reported that up to $80 \%$ of an administered dose of theophylline was eliminated via metabolic transformation. They reported mean urinary recoveries of theophylline and its three major metabolites, 3-methylxanthine (3-MX), 1-methylurate (1-MU), and

From the College of Pharmacy, Department of Pharmacology, the Upjohn Center for Clinical Pharmacology, and the Department of Internal Medicine, School of Medicine, University of Michigan, and Wamer Lambert/Parke Davis Pharmaceutical Research Division.

Supported by a contract between Warner Lambert/Parke Davis and the University of Michigan.

Received for publication Oct. 27, 1987; accepted June 2, 1988.

Reprint requests: John Wagner, $\mathrm{PhD}$, Upjohn Center for Clinical Pharmacology, UJ3705/0504, University of Michigan Medical Center, Ann Arbor, MI 48109. 1,3-dimethylurate $(1,3-\mathrm{MU})$, to be $13.3 \%, 15.7 \%$, $19.8 \%$, and $39.1 \%$, respectively, after an intravenous theophylline dose. When an oral dose of theophylline was administered to the subjects, mean urinary recoveries for theophylline, 3-MX, 1-MU, and 1,3-MU were found to be $13.8 \%, 13.3 \%, 15.0 \%$, and $36.2 \%$, respectively.

Several drugs are known to alter theophylline disposition by either increasing or suppressing its rate of metabolism..$^{4-7}$ Landay et al. ${ }^{4}$ reported a mean increase in theophylline's total clearance of $34 \%$ when each of six healthy subjects was pretreated with phenobarbital for 4 weeks. Boyce et al. ${ }^{5}$ reported that concurrent use of rifampin increased mean total theophylline clearance by $40 \%$ in 10 subjects. Conversely, cimetidine, oral contraceptives, and propranolol have been reported to significantly decrease total theophylline clearance.$^{6-8}$ It is unlikely that changes in plasma protein binding play any significant role in each interaction, because theophylline is only $52.6 \%$ to $65 \%$ bound. ${ }^{9,10}$ Furthermore, in none of the studies cited above did the apparent distribution volume of theophylline change. Presumably, each of these drug interactions could be explained by induction or suppression of one or more of the known major theophylline metabolic pathways.

Recently theophylline has been found to interact pharmacokinetically with the azaquinoline antiinfective agent, enoxacin. Wijnands et al. ${ }^{11}$ reported that eight of 10 patients receiving theophylline developed nausea 
Table I. Mean plasma concentrations of theophylline and its three major inetabolites

\begin{tabular}{|c|c|c|c|c|c|c|c|c|}
\hline \multicolumn{9}{|c|}{ Mean plasma concentration $(m g / L)$ and $S D^{*}$} \\
\hline \multirow{2}{*}{$\begin{array}{l}\text { Time } \\
(h r)\end{array}$} & \multicolumn{4}{|c|}{ Theophylline } & \multicolumn{4}{|c|}{$3-M X$} \\
\hline & $A$ & $B$ & $C$ & $D$ & A & $B$ & $C$ & $D$ \\
\hline 0 & 0 & 0 & 0 & 0 & 0 & 0 & 0 & 0 \\
\hline 1 & $\begin{array}{l}0.462 \\
\quad(0.362)\end{array}$ & $\begin{array}{l}0.679 \\
\quad(0.425)\end{array}$ & $\begin{array}{l}0.373 \\
\quad(0.283)\end{array}$ & $\begin{array}{l}0.326 \\
(0.0974)\end{array}$ & $\begin{array}{l}0.0418 \\
(0.0835)\end{array}$ & 0 & $\begin{array}{l}0.0132 \\
(0.0264)\end{array}$ & $\begin{array}{l}0.0127 \\
\quad(0.0147)\end{array}$ \\
\hline 2 & $\begin{array}{l}0.943 \\
(0.403)\end{array}$ & $\begin{array}{l}1.01 \\
(0.508)\end{array}$ & $\begin{array}{l}0.935 \\
\quad(0.357)\end{array}$ & $\begin{array}{l}0.859 \\
(0.437)\end{array}$ & $\begin{array}{l}0.0485 \\
(0.0739)\end{array}$ & $\begin{array}{l}0.104 \\
(0.0666)\end{array}$ & $\begin{array}{l}0.0352 \\
(0.0431)\end{array}$ & 0 \\
\hline 4 & $\begin{array}{l}1.51 \\
(0.270)\end{array}$ & $\begin{array}{l}1.96 \\
(0.803)\end{array}$ & $\begin{array}{l}1.35 \\
\quad(0.378)\end{array}$ & $\begin{array}{l}1.49 \\
(0.320)\end{array}$ & $\begin{array}{l}0.0802 \\
(0.0696)\end{array}$ & $\begin{array}{l}0.169 \\
(0.125)\end{array}$ & $\begin{array}{l}0.108 \\
\quad(0.0975)\end{array}$ & 0 \\
\hline 6 & $\begin{array}{l}2.55 \\
(0.729)\end{array}$ & $\begin{array}{l}2.77 \\
(1.07)\end{array}$ & $\begin{array}{l}2.82 \\
\quad(0.817)\end{array}$ & $\begin{array}{l}3.26 \\
(1.19)\end{array}$ & $\begin{array}{l}0.101 \\
\quad(0.0849)\end{array}$ & $\begin{array}{l}0.177 \\
\quad(0.109)\end{array}$ & $\begin{array}{l}0.143 \\
\quad(0.105)\end{array}$ & 0 \\
\hline 7 & $\begin{array}{l}2.67 \\
(0.792)\end{array}$ & $\begin{array}{l}3.20 \\
\quad(0.820)\end{array}$ & $\begin{array}{l}3.39 \\
(0.973)\end{array}$ & $\begin{array}{l}3.30 \\
(1.37)\end{array}$ & $\begin{array}{l}0.147 \\
\quad(0.129)\end{array}$ & $\begin{array}{l}0.188 \\
\quad(0.0962)\end{array}$ & $\begin{array}{l}0.123 \\
\quad(0.0893)\end{array}$ & 0 \\
\hline 8 & $\begin{array}{l}2.50 \\
(0.941)\end{array}$ & $\begin{array}{l}3.37 \\
\quad(0.558)\end{array}$ & $\begin{array}{l}3.82 \\
\quad(1.06)\end{array}$ & $\begin{array}{l}3.46 \\
(1.18)\end{array}$ & $\begin{array}{l}0.187 \\
\quad(0.0632)\end{array}$ & $\begin{array}{l}0.155 \\
(0.0846)\end{array}$ & $\begin{array}{l}0.0978 \\
(0.0772)\end{array}$ & 0 \\
\hline 10 & $\begin{array}{l}2.53 \\
(1.07)\end{array}$ & $\begin{array}{l}3.35 \\
(0.555)\end{array}$ & $\begin{array}{l}3.70 \\
\quad(0.565)\end{array}$ & $\begin{array}{l}3.79 \\
(0.956)\end{array}$ & $\begin{array}{l}0.200 \\
(0.0471)\end{array}$ & $\begin{array}{l}0.164 \\
\quad(0.0953)\end{array}$ & $\begin{array}{l}0.0897 \\
(0.0698)\end{array}$ & 0 \\
\hline 12 & $\begin{array}{l}2.05 \\
(0.909)\end{array}$ & $\begin{array}{c}2.68 \\
(1.14)\end{array}$ & $\begin{array}{l}3.30 \\
(0.516)\end{array}$ & $\begin{array}{l}3.78 \\
(0.634)\end{array}$ & $\begin{array}{l}0.134 \\
(0.0529)\end{array}$ & $\begin{array}{l}0.161 \\
\quad(0.103)\end{array}$ & 0 & 0 \\
\hline 24 & $\begin{array}{l}0.749 \\
(0.573)\end{array}$ & $\begin{array}{c}1.23 \\
(0.428)\end{array}$ & $\begin{array}{l}2.00 \\
(0.478)\end{array}$ & $\begin{array}{l}2.79 \\
(0.741)\end{array}$ & $\begin{array}{l}0.0897 \\
(0.0913)\end{array}$ & $\begin{array}{c}0.0517 \\
(0.0708)\end{array}$ & 0 & 0 \\
\hline 30 & $\begin{array}{l}0.385 \\
(0.326)\end{array}$ & $\begin{array}{l}0.945 \\
(0.512)\end{array}$ & $\begin{array}{l}1.47 \\
(0.366)\end{array}$ & $\begin{array}{l}2.03 \\
(0.787)\end{array}$ & $\begin{array}{l}0.0488 \\
(0.0674)\end{array}$ & $\begin{array}{l}0.0390 \\
(0.0525)\end{array}$ & 0 & 0 \\
\hline 36 & 0 & $\begin{array}{c}0.427 \\
(0.348)\end{array}$ & $\begin{array}{c}0.933 \\
(0.368)\end{array}$ & $\begin{array}{c}1.60 \\
(0.702)\end{array}$ & $\begin{array}{l}0.0285 \\
(0.0570)\end{array}$ & $\begin{array}{l}0.0146 \\
(0.0292)\end{array}$ & $\begin{array}{l}0.0253 \\
(0.0505)\end{array}$ & 0 \\
\hline 48 & 0 & 0 & $\begin{array}{c}0.407 \\
(0.379)\end{array}$ & 0 & 0 & 0 & $\begin{array}{l}0.0221 \\
(0.0441)\end{array}$ & 0 \\
\hline 54 & 0 & 0 & $\begin{array}{l}0.289 \\
(0.239)\end{array}$ & 0 & 0 & 0 & 0 & 0 \\
\hline 72 & 0 & 0 & 0 & 0 & 0 & 0 & 0 & 0 \\
\hline
\end{tabular}

Numbers in parentheses are SDs.

*Plasma concentrations less than $0.2 \mathrm{mg} / \mathrm{L}$ for theophylline and $0.02 \mathrm{mg} / \mathrm{L}$ for each metabolite were reported as zero

and vomiting when enoxacin was added to the drug regimen. They found no changes in either plasma protein binding or renal clearance of theophylline when enoxacin was coadministered. Maesen et al. ${ }^{12}$ also found an unusually high rate of theophylline-like toxicity in 12 of 15 patients receiving enoxacin. Side effects included nausea $(n=9)$, vomiting $(n=1)$, epileptiform attack $(n=1)$, dizziness $(n=2)$, hallucinations $(n=1)$, and depersonalization $(n=1)$. Three subjects received enoxacin and theophylline concurrently without reporting side effects. However, 10 of the 12 subjects who had side effects were receiving theophylline concurrently. Wijnands et al. ${ }^{13}$ conducted a follow-up study after their initial observations and reported that enoxacin ( 800 to $1200 \mathrm{mg} /$ day) induced a 2.6-fold increase in mean trough theophylline plasma concentrations in 14 subjects. With these observations in mind, we examined the relationship between the size of the enoxacin dose and plasma concentrations and urinary excretion of theophylline and its metabolites 3-MX, 1-MU, and 1,3-MU.

\section{METHODS}

Study design. The study had a four-subject, fourway crossover design. Each subject received a single $200 \mathrm{mg}$ dose of theophylline during each of four different enoxacin treatments. The control treatment (A) and treatments $\mathrm{B}, \mathrm{C}$, and $\mathrm{D}$ corresponded to enoxacin doses of $0,25,100$, and $400 \mathrm{mg}$ every 12 hours, respectively. Each treatment consisted of oral administration of an enoxacin capsule twice daily for 14 doses. With the administration of the ninth enoxacin dose, 200 $\mathrm{mg}$ theophylline (as Theo-Dur) was administered to each subject. Enoxacin and its major metabolite (the enoxacin-oxo-metabolite), theophylline, 3-MX, 1-MU, and 1,3-MU concentrations were monitored in plasma and urine during the 72-hour period after each theophylline dose. 


\begin{tabular}{|c|c|c|c|c|c|c|c|}
\hline \multicolumn{8}{|c|}{ Mean plasma concentration $(\mathrm{mg} / L)$ and $S D^{*}$} \\
\hline \multicolumn{4}{|c|}{$1-M U$} & \multicolumn{4}{|c|}{$1,3 \cdot M U$} \\
\hline$A$ & $B$ & $C$ & $D$ & $A$ & $B$ & $C$ & $D$ \\
\hline 0 & 0 & 0 & 0 & 0 & 0 & 0 & 0 \\
\hline $\begin{array}{l}0.0249 \\
\quad(0.0295)\end{array}$ & 0 & 0 & $\begin{array}{l}0.114 \\
\quad(0.229)\end{array}$ & $\begin{array}{l}0.233 \\
\quad(0.356)\end{array}$ & 0 & 0 & 0 \\
\hline 0 & $\begin{array}{l}0.0720 \\
\quad(0.0381)\end{array}$ & $\begin{array}{l}0.0384 \\
(0.241)\end{array}$ & $\begin{array}{l}0.0501 \\
\quad(0.0329)\end{array}$ & $\begin{array}{l}0.459 \\
\quad(0.0710)\end{array}$ & $\begin{array}{l}0.0246 \\
(0.791)\end{array}$ & 0 & 0 \\
\hline $\begin{array}{l}0.0822 \\
\quad(0.0381)\end{array}$ & $\begin{array}{l}0.230 \\
(0.241)\end{array}$ & $\begin{array}{l}0.0431 \\
\quad(0.0329)\end{array}$ & $\begin{array}{l}0.0355 \\
\quad(0.0710)\end{array}$ & $\begin{array}{l}0.575 \\
\quad(0.791)\end{array}$ & 0 & 0 & 0 \\
\hline $\begin{array}{l}0.144 \\
\quad(0.119)\end{array}$ & $\begin{array}{l}0.328 \\
(0.297)\end{array}$ & $\begin{array}{l}0.147 \\
\quad(0.181)\end{array}$ & $\begin{array}{l}0.0232 \\
\quad(0.0464)\end{array}$ & $\begin{array}{l}0.587 \\
(0.628)\end{array}$ & $\begin{array}{l}0.160 \\
\quad(0.104)\end{array}$ & 0 & 0 \\
\hline $\begin{array}{l}0.101 \\
\quad(0.0815)\end{array}$ & $\begin{array}{l}0.312 \\
\quad(0.240)\end{array}$ & $\begin{array}{l}0.0872 \\
\quad(0.0533)\end{array}$ & $\begin{array}{l}0.0189 \\
\quad(0.0379)\end{array}$ & $\begin{array}{l}0.536 \\
\quad(0.515)\end{array}$ & $\begin{array}{l}0.153 \\
\quad(0.0917)\end{array}$ & 0 & 0 \\
\hline $\begin{array}{l}0.0895 \\
\quad(0.0526)\end{array}$ & $\begin{array}{l}0.292 \\
(0.237)\end{array}$ & $\begin{array}{l}0.0815 \\
\quad(0.0461)\end{array}$ & $\begin{array}{l}0.0250 \\
\quad(0.0500)\end{array}$ & $\begin{array}{l}0.377 \\
\quad(0.286)\end{array}$ & $\begin{array}{l}0.136 \\
\quad(0.0866)\end{array}$ & $\begin{array}{l}0.0327 \\
(0.0337)\end{array}$ & 0 \\
\hline $\begin{array}{l}0.0897 \\
\quad(0.0749)\end{array}$ & $\begin{array}{l}0.354 \\
\quad(0.293)\end{array}$ & $\begin{array}{l}0.122 \\
\quad(0.121)\end{array}$ & $\begin{array}{l}0.0778 \\
\quad(0.0930)\end{array}$ & $\begin{array}{l}0.493 \\
\quad(0.241)\end{array}$ & $\begin{array}{l}0.139 \\
\quad(0.0745)\end{array}$ & 0 & 0 \\
\hline $\begin{array}{l}0.0873 \\
(0.0743)\end{array}$ & $\begin{array}{l}0.351 \\
\quad(0.313)\end{array}$ & $\begin{array}{l}0.0416 \\
\quad(0.0334)\end{array}$ & $\begin{array}{l}0.0270 \\
\quad(0.0540)\end{array}$ & $\begin{array}{l}0.198 \\
\quad(0.168)\end{array}$ & 0 & 0 & 0 \\
\hline $\begin{array}{l}0.0380 \\
\quad(0.0458)\end{array}$ & $\begin{array}{l}0.239 \\
(0.207)\end{array}$ & $\begin{array}{l}0.0255 \\
\quad(0.0259)\end{array}$ & 0 & $\begin{array}{l}0.0862 \\
(0.0608)\end{array}$ & 0 & $\begin{array}{l}0.0325 \\
(0.0344)\end{array}$ & 0 \\
\hline $\begin{array}{l}0.0236 \\
(0.0473)\end{array}$ & $\begin{array}{l}0.192 \\
\quad(0.213)\end{array}$ & $\begin{array}{c}0.0116 \\
(0.0233)\end{array}$ & 0 & $\begin{array}{l}0.0396 \\
(0.0457)\end{array}$ & $\begin{array}{l}0.0603 \\
(0.0449)\end{array}$ & 0 & 0 \\
\hline $\begin{array}{l}0.0117 \\
\quad(0.0233)\end{array}$ & $\begin{array}{l}0.0868 \\
(0.158)\end{array}$ & $\begin{array}{l}0.0671 \\
\quad(0.0848)\end{array}$ & 0 & $\begin{array}{l}0.0207 \\
\quad(0.0273)\end{array}$ & $\begin{array}{l}0.0334 \\
\quad(0.0394)\end{array}$ & 0 & 0 \\
\hline 0 & 0 & $\begin{array}{l}0.0458 \\
\quad(0.0763)\end{array}$ & 0 & 0 & 0 & 0 & 0 \\
\hline 0 & 0 & $\begin{array}{l}0.0263 \\
\quad(0.0525)\end{array}$ & 0 & 0 & 0 & 0 & 0 \\
\hline 0 & 0 & 0 & 0 & 0 & 0 & 0 & 0 \\
\hline
\end{tabular}

The four subjects who participated in the study were healthy, male, nonsmoking volunteers. Their ages ranged from 22 to 27 years (mean $251 / 2$ years) and their weights from 156 to 180 pounds (mean 164 pounds). Each subject gave written, informed consent to participate in the study and each subject had normal vital signs and laboratory screening parameters. All subjects adhered to a strict xanthine-free diet beginning 3 days before the first enoxacin dose and extending for 3 days after the single theophylline dose.

Blood sampling consisted of drawing $7 \mathrm{ml}$ samples from a forearm vein with heparinized vacutainers. The samples were drawn at 0 (just before the theophylline dose) and 1, 2, 4, 6, 7, 8, 10, 12, 24, 30, 36, 48, 54, and 72 hours after theophylline dose. The plasma was immediately separated from the sample, quick frozen, and stored at $-20^{\circ} \mathrm{C}$ until assayed.

Just before theophylline administration, each subject voided all urine. Urine was then collected during the following intervals: 0 to 2,2 to 6,6 to 8,8 to 12,12 to 24,24 to 48 , and 48 to 72 hours. The urine volumes from each collection period were measured and recorded; a $10 \mathrm{ml}$ aliquot of each collection was kept for assays. Each aliquot was immediately frozen and stored at $-20^{\circ} \mathrm{C}$ until assayed. All plasma and urine samples were assayed for parent drugs and metabolites within 2 weeks.

Analysis. The HPLC assay methods for determining theophylline, 3-MX, 1-MU, and 1,3-MU concentrations in plasma and urine were modifications of those developed by Tang-Liu et al. ${ }^{3}$ The HPLC apparatus consisted of a Waters 501 solvent delivery pump (Waters Associates, Milford, Mass.) in series with a Waters WISP $710 \mathrm{~B}$ injector. The main column was a Beckman $\mathrm{C}_{18}$, Ultrasphere ODS, $5 \mu \mathrm{m}, 4.6 \mathrm{~mm}$ by $250 \mathrm{~mm}$ (Beckman Instruments, Inc., Fullerton, Calif.). It was water jacketed (model T-2, Lauda RC3, Brinkmann Instruments, Inc., Westbury, N.Y.) and kept at a constant temperature of $25^{\circ} \mathrm{C}$. Detection of the analytes was accomplished with a Waters model 440 ultraviolet 
Table II. Theophylline pharmacokinetic parameters

\begin{tabular}{lcccccc}
\hline & \multicolumn{5}{c}{ Mean parameter value after indicated treatment } \\
\cline { 2 - 6 } \multicolumn{1}{c}{ Parameter } & $A$ & $B$ & $C$ & $D$ & $p$ Value* & $I-\beta \dagger$ \\
\hline AUC $(\mathrm{mg} \cdot \mathrm{hr} / \mathrm{L})$ & $44.2(24.2)$ & $62.9(14.2)$ & $88.8(23.9)$ & $121(50)$ & 0.0001 & $>0.99$ \\
Oral clearance $(\mathrm{ml} / \mathrm{min})$ & $117(107)$ & $55.1(12.6)$ & $39.3(9.0)$ & $31.1(12.3)$ & 0.161 & 0.35 \\
$\mathrm{C}_{\max }(\mathrm{mg} / \mathrm{L})$ & $2.81(0.84)$ & $3.65(0.55)$ & $4.00(0.85)$ & $4.02(0.84)$ & 0.004 & 0.97 \\
$\mathrm{t}_{\max }(\mathrm{hr})$ & $8.00(2.31)$ & $7.75(1.71)$ & $9.00(1.15)$ & $10.3(2.36)$ & - & - \\
$\mathrm{k}_{\mathrm{e}}\left(\mathrm{hr}^{-1}\right)$ & $0.0919(0.0184)$ & $0.0788(0.0353)$ & $0.0535(0.010)$ & $0.0680(0.0475)$ & 0.453 & $<0.2$ \\
Elimination $\mathrm{t}_{1 / 2}(\mathrm{hr})$ & $7.78(1.66)$ & $10.5(5.19)$ & $13.5(2.52)$ & $14.2(8.55)$ & - & - \\
\hline
\end{tabular}

Numbers in parentheses are SDs.

* Significance of difference among treatment mean squares of the ANOVA for crossover design.

tPower of the ANOVA (the probability of detecting the difference in treatment means).

detector set at $280 \mathrm{~nm}$. The ultraviolet absorption response was traced by a Linear recorder (Linear Instruments Corp., Reno, Nev.). The mobile phase consisted of methanol mixed with a solution of $10 \mathrm{mmol} / \mathrm{L}$ sodium acetate and $5 \mathrm{mmol} / \mathrm{L}$ tetrabutylammonium hydrogen sulfate adjusted to $\mathrm{pH} 4.75$ with glacial acetic acid or $1 \mathrm{~mol} / \mathrm{L}$ sodium hydroxide. The ratio of methanol to aqueous buffer was $12 / 88, \mathrm{vol} / \mathrm{vol}$; the flow rate was $1.4 \mathrm{ml} / \mathrm{min}$.

Plasma samples were prepared for analysis by first transferring $0.5 \mathrm{ml}$ plasma to a $7 \mathrm{ml}$ glass culture tube $(13 \mathrm{~mm}$ by $100 \mathrm{~mm}$ ). To each sample was added $2 \mathrm{ml}$ acetonitrile containing $2.5 \mu \mathrm{g} / \mathrm{ml}$ of internal standard ( $\beta$-hydroxyethyltheophylline). The mixture was vortexed for 20 seconds and then centrifuged at $2000 \mathrm{~g}$ for 10 minutes to sediment the precipitated protein. The supernatant was then transferred to a $10 \mathrm{ml}$ glass culture tube $(16 \mathrm{~mm}$ by $100 \mathrm{~mm})$ and vortexed in a Haake Buchler vortex evaporator (Haake Inc., Saddle Brook, N.J.) at $40^{\circ} \mathrm{C}$ for 40 minutes. The remaining solution was then centrifuged for 4 minutes at $12,800 \mathrm{~g}$ in an Eppendorf microcentrifuge (Brinkmann). A $50 \mu \mathrm{l}$ volume of supernatant was injected via the WISP onto the HPLC column. Theophylline plasma concentrations were monitored over the range of $0.200 \mathrm{mg} / \mathrm{L}$ to 10.0 $\mathrm{mg} / \mathrm{L}$; 3-MX, 1-MU, and 1,3-MU plasma concentrations were monitored over the range of $0.0200 \mathrm{mg} / \mathrm{L}$ to $1 \mathrm{mg} / \mathrm{L}$.

Urine samples were prepared for injection by adding $0.5 \mathrm{ml}$ urine to $0.5 \mathrm{ml} 0.1 \mathrm{~mol} / \mathrm{L}$ tetrabutylammonium hydrogen sulfate and $0.25 \mathrm{ml}$ carbonate buffer in a screw-capped centrifuge tube. The carbonate buffer $(\mathrm{pH}$ 11) was prepared by mixing a $0.1 \mathrm{~mol} / \mathrm{L}$ sodium carbonate solution with a $0.1 \mathrm{~mol} / \mathrm{L}$ sodium bicarbonate solution in a $9 / 1$, vol/vol ratio. The solution of urine, ion-pairing agent, and buffer were vortexed for $10 \mathrm{sec}$ onds followed by the addition of $1 \mathrm{gm}$ ammonium sul- fate. The mixture was vortexed again for 30 seconds. To the mixture was added $10 \mathrm{ml}$ extraction solvent (ethyl acetate, chloroform, isopropanol, 45/45/10, $\mathrm{vol} / \mathrm{vol} / \mathrm{vol}$, and $\beta$-hydroxyethyltheophylline, 7.5 $\mathrm{mg} / \mathrm{L}$ ). The mixture was vortexed for 1 minute followed by centrifugation for 10 minutes at $2000 \mathrm{~g}$. To a glass culture tube $(16 \mathrm{~mm}$ by $100 \mathrm{~mm})$ was added $5 \mathrm{ml}$ of the upper organic layer. In a $40^{\circ} \mathrm{C}$ water bath and under a gentle stream of nitrogen, the organic solution was evaporated to dryness. The residue was then reconstituted with $1 \mathrm{ml}$ of a $50 \mathrm{mmol} / \mathrm{L}$ tetrabutylammonium hydrogen sulfate $/ 10 \mathrm{mmol} / \mathrm{L}$ sodium acetate $/ 10 \%$ methanol $(\mathrm{vol} / \mathrm{vol} / \mathrm{vol})$ solution. To ensure maximum dissolution of the analytes, the tubes were vortexed for 30 seconds; $50 \mu$ lof the reconstituted solution was then injected onto the column. Theophylline and its three major metabolites were monitored over a concentration range of 1 to $100 \mathrm{mg} / \mathrm{L}$.

The assay method employed to determine enoxacin and the enoxacin-oxo-metabolite in plasma and urine used the same HPLC system as that used for theophylline assays. The only differences were that a Beckman $\mathrm{C}_{8}$ column was used (all column dimensions were similar) and ultraviolet detection was performed at $340 \mathrm{~nm}$. The mobile phase consisted of a $1 \mathrm{mmol} / \mathrm{L}$ 1-pentanesulfonic acid solution, adjusted to a $\mathrm{pH}$ of 2.5 with concentrated phosphoric acid, and ethanol in a ratio of $65 / 35, \mathrm{vol} / \mathrm{vol}$. The flow rate was set at 0.7 $\mathrm{ml} / \mathrm{min}$.

Plasma samples were prepared for injection by mixing $1 \mathrm{ml}$ plasma with $1 \mathrm{ml} \mathrm{5 \%}$ trichloroacetic acid/acetonitrile $(1 / 1, \mathrm{vol} / \mathrm{vol})$ in a $16 \mathrm{~mm}$ by $100 \mathrm{~mm}$ glass culture tube. Each sample mixture was vortexed for 20 seconds and allowed to sit for 20 minutes. Samples were vortexed again for 5 seconds and $1.5 \mathrm{ml}$ of each was spun in an Eppendorf centrifuge at $12,800 \mathrm{~g}$ for 10 minutes. Exactly $20 \mu \mathrm{l}$ supernatant was then 
Table III. Mean AUCs

\begin{tabular}{lccccccc}
\hline & \multicolumn{9}{c}{$A U C(m g \cdot h r / L)$} & & \\
\cline { 2 - 5 } Metabolite & $A$ & $B$ & $C$ & $D$ & & $p$ Value* & $1-\beta \dagger$ \\
\hline 3-MX & $3.15(2.48)$ & $2.84(1.84)$ & $2.18(2.66)$ & $0.300(0.288)$ & 0.221 & 0.29 \\
1-MU & $1.83(1.56)$ & $8.32(7.50)$ & $2.33(1.73)$ & $0.290(0.534)$ & 0.138 & 0.40 \\
1,3-MU & $7.31(2.95)$ & $3.30(2.16)$ & $0.787(1.12)$ & $0(0)$ & 0.016 & 0.83 \\
\hline
\end{tabular}

Numbers in parentheses are SDs.

*Significance of difference among treatment mean squares of the ANOVA for crossover design.

†Power of the ANOVA (probability of detecting the difference in treatment means).

injected onto the column via the WISP. Concentrations of enoxacin were monitored over a range of 0.10 to 10 $\mathrm{mg} / \mathrm{L}$; the oxo-metabolite was monitored over a range of 0.20 to $2 \mathrm{mg} / \mathrm{L}$.

Urine samples were prepared by initially diluting each twentyfold with double-distilled, deionized water. To $1 \mathrm{ml}$ of the diluted urine was added $2 \mathrm{ml}$ of ethyl acetate in a $16 \mathrm{~mm}$ by $100 \mathrm{~mm}$ glass culture tube. The sample was then vortexed for 30 seconds and centrifuged at $2000 \mathrm{~g}$ for 10 minutes. The upper organic layer was removed and $10 \mu \mathrm{l}$ of the remaining aqueous layer could then be injected onto the column. Enoxacin was monitored over a concentration range of 5 to 200 $\mathrm{mg} / \mathrm{L}$; the oxo-metabolite was monitored over a range of 1 to $40 \mathrm{mg} / \mathrm{L}$.

Assay sensitivity and reproducibility. The lowest concentration on the plasma standard curves was 0.2 $\mathrm{mg} / \mathrm{L}$ plasma for theophylline and $0.02 \mathrm{mg} / \mathrm{L}$ plasma for each theophylline metabolite. The lowest concentration on the plasma standard curves was 0.100 $\mathrm{mg} / \mathrm{L}$ plasma for enoxacin and $0.200 \mathrm{mg} / \mathrm{L}$ for the enoxacinoxo-metabolite. Corresponding concentrations for urine were $1 \mathrm{mg} / \mathrm{L}$ for theophylline and each theophylline metabolite, $2 \mathrm{mg} / \mathrm{L}$ for enoxacin, and 2 $\mathrm{mg} / \mathrm{L}$ for the enoxacin-oxo-metabolite. These concentrations were considered to be the assay sensitivities and all concentrations measured below these values were taken as zero.

Each assay was validated by measuring the concentration of five to seven samples of each of these different concentrations on each of 3 different days. Plasma concentrations used for theophylline were $0.200,1.00$, $5.00,10.0$, and $20.0 \mathrm{mg} / \mathrm{L}$, those for each theophylline metabolite were $0.0500,0.100,0.500,1.00$, and 2.00 $\mathrm{mg} / \mathrm{L}$, those for enoxacin were $0.25,0.500,1.00$, $2.50,5.00,7.50$, and $10 \mathrm{mg} / \mathrm{L}$, and those for the enoxacin-oxo-metabolite were $0.05,0.100,0.200$, $0.500,1.00,1.50$, and $2.0 \mathrm{mg} / \mathrm{L}$. During analysis of study plasma and urine samples quality control samples were also analyzed along with the unknowns.
Pharmacokinetic analysis. Oral clearance (CL/F) of theophylline was calculated as dose/AUC. The bioavailability (F) could not be estimated because some metabolites of theophylline were not measurable because they are unknown. First-order elimination rate constants $\left(k_{e}\right)$ were estimated by least-squares linear regression of the terminal log-linear plasmaconcentration-time data. The plasma elimination halflife $\left(t_{1 / 2}\right)$ was determined by dividing $k_{e}$ into 0.693 . To estimate the AUC the trapezoidal rule was employed. Molar fraction-recovered values were estimated by converting each amount recovered in urine into molar equivalents and then dividing those numbers by the molar amount of theophylline dosed to each subject. The molecular weights of theophylline, 3-MX, 1-MU, and 1,3-MU are 180.2, 166.1, 182.1, and 196.2, respectively. If it is assumed that Theo-Dur is $100 \%$ bioavailable, each subject should have absorbed $200 \mathrm{mg}$ theophylline $(1.11 \mathrm{mmol} / \mathrm{L})$. Renal clearances were estimated by dividing the amount of compound recovered in urine during each 12-hour time period by the compound's respective plasma AUC during the same time period.

Statistical analysis. The 27 assay values (three concentrations for 3 days for three replicates) for each compound, expressed as a percent of the known and obtained during assay validation, were analyzed by twofactor ANOVA in which mean squares were calculated for concentrations, days, and error.

The 16 values (four subjects given four enoxacin doses) for each measured quantity or parameter were analyzed by ANOVA for crossover design ${ }^{13}$ in which mean squares were calculated for subjects, treatments, time periods, and residual. The significance levels ( $p$ values) of the treatment mean squares are listed in Tables II, III, and IV. In addition, the power of the ANOVA, $1-\beta$, was calculated ${ }^{14}$ in each case and these values are listed in Tables II, III, and IV also. The $1-\beta$ values are the probabilities of detecting at $\alpha=0.05$ the differences in means observed. 
Table IV. Mean amounts of theophylline and its three major metabolites excreted in urine in the 72 -hour sampling period

\begin{tabular}{lccccccc}
\hline & \multicolumn{9}{c}{ Mean amount excreted } & after indicated treatment $(\mathrm{mg})$ & & & \\
\cline { 2 - 5 } Compound & $A$ & $B$ & $C$ & $D$ & & $p$ Value* & $1-\beta \dagger$ \\
\hline Theophylline & $29.2(12.2)$ & $28.2(10.7)$ & $48.2(13.1)$ & $46.1(13.5)$ & & 0.085 & 0.50 \\
3-MX & $23.4(22.2)$ & $16.0(9.8)$ & $35.5(32.3)$ & $6.31(4.29)$ & 0.306 & 0.25 \\
1-MU & $34.9(22.4)$ & $61.2(18.0)$ & $45.7(21.9)$ & $10.4(6.6)$ & 0.015 & 0.86 \\
1,3-MU & $99.4(16.8)$ & $45.9(23.9)$ & $27.7(10.1)$ & $26.3(8.2)$ & 0.0005 & $>0.99$ \\
\hline
\end{tabular}

Numbers in parentheses are SDs.

* Significance of difference among treatment mean squares of the ANOVA for crossover design.

$\dashv$ Power of the ANOVA (probability of detecting the difference in treatment means).

Table V. Mean plasma concentrations of enoxacin and its oxo-metabolite

\begin{tabular}{|c|c|c|c|c|c|c|}
\hline \multirow{3}{*}{$\begin{array}{c}\text { Time } \\
(h r)\end{array}$} & \multicolumn{6}{|c|}{ Mean plasma concentration $(m g / L) *$} \\
\hline & \multicolumn{3}{|c|}{ Enoxacin } & \multicolumn{3}{|c|}{ Oxo-metabolite } \\
\hline & $B$ & $C$ & $D$ & $B$ & C & $D$ \\
\hline $0 \dagger$ & 0 & $0.134(0.0372)$ & $0.594(0.425)$ & 0 & 0 & 0 \\
\hline 1 & $0.153(0.0484)$ & $0.471(0.0423)$ & $1.71(0.189)$ & 0 & $0.111(0.223)$ & 0 \\
\hline 2 & 0 & $0.640(0.229)$ & $1.94(0.664)$ & 0 & 0 & $0.209(0.160)$ \\
\hline 4 & 0 & $0.438(0.208)$ & $1.59(0.547)$ & 0 & 0 & $0.184(0.128)$ \\
\hline 6 & 0 & $0.330(0.187)$ & $1.30(0.466)$ & 0 & 0 & $0.298(0.0753)$ \\
\hline 7 & 0 & $0.257(0.141)$ & $1.00(0.159)$ & 0 & $0.0500(0.100)$ & 0 \\
\hline 8 & 0 & $0.226(0.139)$ & $0.845(0.320)$ & 0 & 0 & 0 \\
\hline 10 & 0 & $0.168(0.0684)$ & $0.693(0.232)$ & 0 & $0.0500(0.100)$ & 0 \\
\hline $12 \dagger$ & 0 & $0.173(0.156)$ & $0.886(0.548)$ & 0 & 0 & 0 \\
\hline $24 \dagger$ & 0 & $0.191(0.109)$ & $0.686(0.491)$ & 0 & $0.0500(0.100)$ & $0.0778(0.156)$ \\
\hline 30 & 0 & $0.289(0.137)$ & $1.08(0.557)$ & 0 & 0 & $0.0870(0.174)$ \\
\hline $36 \dagger$ & 0 & 0 & $0.744(0.469)$ & 0 & 0 & $0.193(0.135)$ \\
\hline $48 \dagger$ & 0 & 0 & $1.01(0.606)$ & 0 & 0 & $0.206(0.147)$ \\
\hline 54 & 0 & $0.241(0.0987)$ & $1.22(0.426)$ & 0 & 0 & 0 \\
\hline $72 \dagger$ & 0 & $0.179(0.109)$ & $0.657(0.515)$ & 0 & 0 & 0 \\
\hline
\end{tabular}

Numbers in parentheses are SDs.

*Plasma concentrations less than the lowest point on the standard curves, namely $0.10 \mathrm{mg} / \mathrm{L}$ for enoxacin and $0.05 \mathrm{mg} / \mathrm{L}$ for the oxo-metabolite, were recorded as zero.

†Enoxacin was administered every 12 hours, hence these are times of dosing.

\section{RESULTS}

Assay reproducibility. In each two-factor ANOVA of the plasma assay validation data for theophylline and its three metabolites none of the mean squares for concentrations (expressed as a percentage of the known concentrations) and days were significant. Coefficients of variation calculated from the root mean square errors were $5.02 \%, 4.51 \%, 5.56 \%$, and $5.15 \%$ for theophylline 3-MX, 1-MU, and 1,3-MU, respectively. Coefficients of variation calculated from the pooled 27 values for each compound were $4.85 \%, 4.85 \%, 5.62 \%$, and $5.23 \%$, respectively, for the compounds in the same order. Analysis of urinary data gave similar results. Assay validation for enoxacin gave coefficients of vari- ation ranging from $2.33 \%$ to $6 \%$ and validation for the enoxacin-oxo-metabolite gave coefficients of variation ranging from $4.04 \%$ to $5.06 \%$.

Coefficients of variation estimated from the assay of quality control standards at the same time as assay of the unknowns were of the same order of magnitude as those listed above.

Theophylline and metabolites. Mean plasma concentrations of theophylline and its three measured metabolites at each sampling time are listed in Table I. Table II lists the mean theophylline pharmacokinetic parameters along with the significance levels ( $p$ values) of the treatment mean squares of the ANOVA for crossover design and the power $(1-\beta)$ values of the 


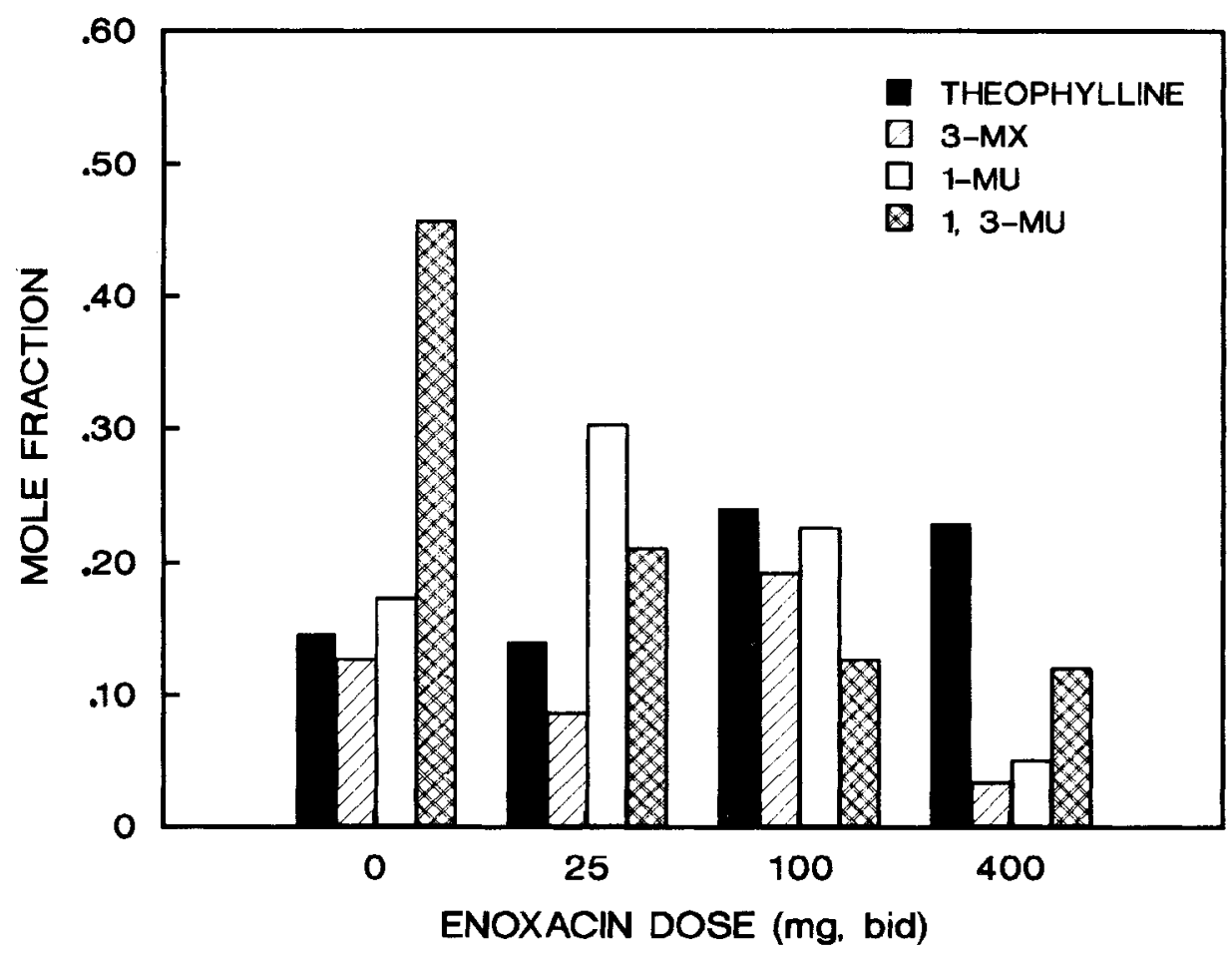

Fig. 1. Mean molar fractions of theophylline and its major metabolites recovered during the 72hour urine collection period.

Table VI. Correlation coefficients and their significance levels for correlation of $\mathrm{x}=$ enoxacin dose and $\mathrm{y}=$ the natural logarithm of the pharmacokinetic parameter ( $n=16$ in each case)

\begin{tabular}{lrc}
\hline $\begin{array}{c}\text { Pharmacokinetic parameter } \\
(\text { mg every 12 hr })\end{array}$ & $r$ & $p$ Value \\
\hline Urinary recovery of theophylline $(\mathrm{mg})$ & 0.458 & 0.074 \\
Urinary recovery of 3-MX (mg) & -0.476 & 0.061 \\
Urinary recovery of 1-MU (mg) & -0.724 & 0.002 \\
Urinary recovery of 1,3-MU (mg) & -0.530 & 0.034 \\
$\mathrm{C}_{\max }(\mathrm{mg} / \mathrm{L})$ & 0.355 & 0.177 \\
$\mathrm{t}_{\max }(\mathrm{hr})$ & 0.453 & 0.078 \\
$\mathrm{CL} / \mathrm{F}(\mathrm{ml} / \mathrm{min})$ & -0.594 & 0.0152 \\
$\mathrm{k}_{\mathrm{e}}\left(\mathrm{hr} \mathrm{I}^{-1}\right)$ & -0.299 & 0.260 \\
$\mathrm{t}_{1 / 2}(\mathrm{hr})$ & 0.294 & 0.269 \\
$\mathrm{AUC}(\mathrm{mg} / \mathrm{L} \cdot \mathrm{hr})$ & 0.594 & 0.0152
\end{tabular}

ANOVAs. It can be seen that there is a general trend in AUC, peak plasma drug concentration $\left(\mathrm{C}_{\max }\right)$, time to reach peak concentration $\left(\mathrm{t}_{\max }\right)$, and elimination $\mathrm{t}_{1 / 2}$ to increase as the enoxacin dose increases. The differences among treatment areas are highly significant $(p=0.0001)$ with very high power $(1-\beta>0.99)$. However, the oral clearance, reciprocally related to AUC, has a $p$ value of only 0.161 , with $1-\beta=0.35$. The increase in AUC of theophylline with increase in enoxacin dose was marginally correlated $(r=0.594)$. However, differences among treatment mean maximum plasma concentrations of theophylline were highly significant $(p=0.004)$ with high power $(1-\beta=$ $0.97)$. Differences among mean elimination rate constants of theophylline were not significant ( $p=0.453$ ).

Table III lists mean AUCs with the $p$ and $1-\beta$ values. Although there is a trend for the area to decrease for each metabolite with an increase in the enoxacin 
dose, only the differences among treatment means for the 1,3-MU metabolite are significant $(p=0.016)$ with high power $(1-\beta>0.83)$.

Table IV lists the mean amounts of theophylline and its metabolites excreted in urine in the 72-hour sampling period along with the $p$ and $1-\beta$ values. Differences among mean amounts of both the $1=$ MU $(p=$ $0.015 ; 1-\beta=0.86)$ and the $1,3-\mathrm{MU}(p<0.0005$; $1-\beta>0.99)$ metabolites are highly significant with high power, whereas differences among means of theophylline and 3-MX have $p$ values greater than 0.05 . Fig. 1 illustrates the relative change in the mean mole fraction of theophylline and its three metabolites recovered in urine for each of the four treatments.

There were no changes in renal clearance of theophylline or its major metabolite when enoxacin was added to the dosage regimen.

Enoxacin and oxo-metabolite. Table $\mathrm{V}$ lists the mean plasma concentrations of enoxacin and its oxometabolite at each sampling time.

Correlations. Table VI lists correlation coefficients for linear regressions of $\mathrm{x}=$ enoxacin dose and $\mathrm{y}=$ natural logarithm of a pharmacokinetic parameter, where $n=16$ in each case. The correlation coefficients were significant $(p<0.05)$ in the cases of urinary recovery of 1-MU, urinary recovery of $1,3-\mathrm{MU}$, oral clearance, and AUC. Logarithmic transformation was used because rectilinear plots of the data were curvilinear. Thus, although the differences in mean parameter values sometimes did not achieve significance, the data trends were significant as indicated by regression.

\section{DISCUSSION}

The results of this study indicate that enoxacin exerts an effect on theophylline metabolism. This effect appears to be a dose-dependent suppression of theophylline's three major metabolic pathways.

This effect on metabolism is evident by relating the enoxacin dose to theophylline's pharmacokinetic profile. Both the theophylline plasma AUC and $\mathrm{C}_{\max }$ values were increased significantly by enoxacin administration. There were also general trends in theophylline's $\mathrm{CL} / \mathrm{F}$ and $\mathrm{t}_{1 / 2}$ to indicate that the drug's elimination was suppressed. There were no changes in renal clearance for theophylline or its major metabolites when enoxacin was added to the dosage regimen.

The apparent cause of this change in theophylline disposition was suppression of oxidative metabolism. The degree of suppression was dependent on the dose of enoxacin given. The mean amount of 3-MX recovered in urine fell almost fourfold from control (no enoxacin) to the $400 \mathrm{mg}$ enoxacin dose level. Similarly, the mean amount of 1,3-MU recovered in urine fell fourfold from control to the $400 \mathrm{mg}$ enoxacin dose level. The mean amount of 1-MU recovered in urine fell by more than threefold from control to the $400 \mathrm{mg}$ enoxacin dose level.

Other studies ${ }^{11,13}$ conducted on the theophyllineenoxacin interaction report that therapeutic doses of enoxacin will increase plasma theophylline levels twofold to threefold. Our study confirms this and indicates that the elevation is dose dependent.

Finally, our results imply that the interaction is unlikely to become more significant when the daily dose of enoxacin exceeds $400 \mathrm{mg}$ every 12 hours, because the change in oral clearance appeared to be asymptotic at the $400 \mathrm{mg}$ enoxacin dose. Thus theophylline dosages will unlikely need to be decreased by more than $66 \%$ when enoxacin dosage exceeds $400 \mathrm{mg}$ twice daily.

We will subsequently report results of another study in which the onset and disappearance of the enoxacintheophylline interaction was studied.

\section{References}

1. Gilman AG, Goodman LS, Gilman A, eds. Goodman and Gilman's the pharmacological basis of therapeutics. 7th ed. New York: Macmillan, 1985:595-6.

2. Jusko WJ, Gardner MJ, Mangione A, Schentag JJ, Koup JR, Vance JW. Factors affecting theophylline clearances: age, tobacco, marijuana, cirrhosis, congestive heart failure, obesity, oral contraceptives, benzodiazepines, barbiturates, and ethanol. J Pharm Sci 1979;68:1358-66.

3. Tang-Liu DD, Williams RL, Riegelman S. Nonlinear theophylline elimination. Clin Pharmacol THeR 1982;31:358-69.

4. Landay RA, Gonzales MA, Taylor JC. Effects of phenobarbital on theophylline disposition. J Allergy Clin Immunol 1978;62:27-9.

5. Boyce EG, Dukes GE, Rollins DE, Sudds TW. The effects of rifampin on theophylline kinetics. J Clin Pharmacol 1986;26:696-9.

6. Cohen IA, Johnson CE, Berardi RR, Hyneck ML, Schem SR. Cimetidine-theophylline interaction: effects of age and cimetidine dose. Ther Drug Monit 1985;7:426-34.

7. Tornatore KM, Kanarkowski R, McCarthy TL, Gardner MJ, Yurchak AM, Jusko WJ. Effect of chronic oral steroids on theophylline disposition. Eur J Clin Pharmacol 1982;23:129-34.

8. Conrad KA, Nyman DW. Effects of metoprolol and propranolol on theophylline elimination. Clin Pharmacol THER 1980;28:463-7.

9. Piafsky KM, Sitar DS, Rangno RE, Ogilvie RI. Theophylline disposition in patients with hepatic cirrhosis. N Engl J Med 1977;296:1495-7.

10. Mangione A, Imhoff TE, Lee RV, Shum LY, Jusko WJ. Pharmacokinetics of theophylline in hepatic disease. Chest 1978;73:616-22. 
11. Wijnands WJA, Van Herwaarden CLA, Vree TB. Enoxacin raises plasma theophylline concentrations. Lancet 1984;ii:108-9.

12. Maesen FPV, Teengs JP, Baur C, Davies BI. Enoxacin raises plasma theophylline levels. Lancet 1984;ii:530.

13. Wijnands WJA, Van Herwaarden CLA, Vree TB. En- oxacin decreases the clearance of theophylline in man. Br J Clin Pharmacol 1985;20:583-8.

14. Wagner JG. Fundamentals of clinical pharmacokinetics. Hamilton, IL: Drug Intelligence Publications, 1975;295:301-4.

Bound volumes available to subscribers

Bound volumes of Clinical Pharmacology \& Therapeutics are available to subscribers (only) for the 1988 issues from the Publisher, at a cost of $\$ 53.00$ ( $\$ 65.00$ international) for Vol. 43 (January-June) and Vol. 44 (July-December). Shipping charges are included. Each bound volume contains a subject and author index and all advertising is removed. Copies are shipped within 60 days after the publication of the last issue of the volume. The binding is durable buckram with the journal name, volume number, and year stamped in gold on the spine. Payment must accompany all orders. Contact The C.V. Mosby Company, Circulation Department, 11830 Westline Industrial Drive, St. Louis, Missouri 63146-3318, USA; phone (800)325-4177, ext. 351.

Subscriptions must be in force to qualify. Bound volumes are not available in place of a regular journal subscription. 